This article was downloaded by: [Loke, Beverley]

On: 17 September 2009

Access details: Access Details: [subscription number 915035891]

Publisher Routledge

Informa Ltd Registered in England and Wales Registered Number: 1072954 Registered office: Mortimer House, 37-41 Mortimer Street, London W1T 3JH, UK

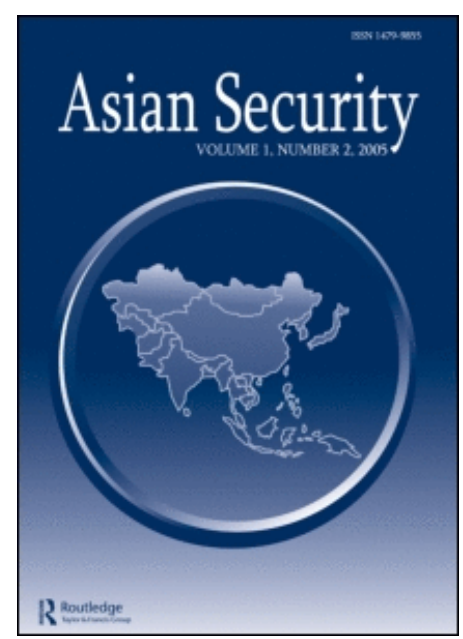

\title{
Asian Security
}

Publication details, including instructions for authors and subscription information:

http://www.informaworld.com/smpp/title content=t713727944

\section{Between Interest and Responsibility: Assessing China's Foreign Policy and Burgeoning Global Role \\ Beverley Loke}

Online Publication Date: 01 September 2009

To cite this Article Loke, Beverley(2009)'Between Interest and Responsibility: Assessing China's Foreign Policy and Burgeoning Global Role',Asian Security, 5:3,195 - 215

To link to this Article: DOI: $10.1080 / 14799850903178899$

URL: http://dx.doi.org/10.1080/14799850903178899

\section{PLEASE SCROLL DOWN FOR ARTICLE}

\footnotetext{
Full terms and conditions of use: http://www.informaworld.com/terms-and-conditions-of-access.pdf

This article may be used for research, teaching and private study purposes. Any substantial or systematic reproduction, re-distribution, re-selling, loan or sub-licensing, systematic supply or distribution in any form to anyone is expressly forbidden.

The publisher does not give any warranty express or implied or make any representation that the contents will be complete or accurate or up to date. The accuracy of any instructions, formulae and drug doses should be independently verified with primary sources. The publisher shall not be liable for any loss, actions, claims, proceedings, demand or costs or damages whatsoever or howsoever caused arising directly or indirectly in connection with or arising out of the use of this material.
} 


\title{
Between Interest and Responsibility: Assessing China's Foreign Policy and Burgeoning Global Role
}

\author{
BEVERLEY LOKE
}

\begin{abstract}
This article is situated within the contemporary debates about the nature and purpose of China's growing power. It uses the concepts of "national interest" and "international responsibility" as a framework of analysis for Chinese foreign policy, and develops a threedimensional typology to conceptualize their relationship (antagonistic; instrumental; mutually constitutive). This article adopts two main arguments. First, a stronger China is one gravitating toward greater notions of international responsibility, albeit instrumentally. Second, observable trends in China's evolving worldview indicate, however, that it is conceiving its national interests more broadly, embracing further socialization and greater normative commitments to international society. One may therefore view China's burgeoning global role as a great power with a degree of "cautious optimism."
\end{abstract}

\section{Introduction}

China's rise has gained increasing attention in international security discourse, albeit with different and often contested interpretations. Contemporary discussions surrounding China's rise have moved beyond examining China's nominal capabilities to also reflect concerns about the purpose of its growing power and its impact on international order. Implications of China's rising power are increasingly being consolidated under the theme of "great power responsibility," with scholars and policy makers focused on whether a stronger China is one more prone to accept international responsibilities and duties. Yet this notion of responsibility is ambiguously defined in international politics. In addition, discussions of how the People's Republic of China (PRC) should translate its rising power into greater political influence often fail to specify to whose interests this should be implemented. This begs the fundamental questions of where China might actually fit into what is still arguably a Western-centric liberal world order and how China will define its role as a great power.

It is within the expanding debates on China's rise and its role as an international actor that this article is situated. Particular attention is directed toward how the pursuit of national interest and the demands of international responsibility interplay in China's foreign policy. As a great power is expected to fulfill international obligations commensurate with its great power status, it is important to examine the extent to which China is doing so. This article therefore focuses on the notions of "national interest" and "international responsibility" in international society, and investigates how they interplay in China's foreign policy. Examining the relationship between China's

I would like to thank Bill Tow, Ralf Emmers, and two anonymous reviewers for their valuable comments. Address correspondence to: Beverley Loke, Department of International Relations, Research School of Pacific and Asian Studies, College of Asia and the Pacific, The Australian National University, Canberra, ACT 0200, Australia. E-mail: Beverley.loke@anu.edu.au 
interests and international responsibility provides a unique perspective from which to identify key patterns in its foreign policy behavior and hence to make an informed assessment of its burgeoning global role as a great power. To this end, this article proposes a new three-dimensional typology to distinguish the conceptual interplay between great power interest and responsibility, where the relationship between interest and responsibility may be antagonistic, instrumental, or mutually constitutive. Collectively, these three categories form a spectrum from which the future direction of China's global role can be assessed. By applying this framework, two central questions are addressed here: How do the pursuit of national interest and the demands of international responsibility interplay in China's foreign policy; and what are the implications for its burgeoning global role as a great power?

This article advances two major arguments. First, the interplay between interest and responsibility in China's foreign policy falls mainly in the second category of the above stipulated typology; that is, China's responsible behavior is driven more by an instrumental calculation of its national interests. Although China is undeniably aspiring to play a global role, such aspirations have yet to be translated into long-term strategies and policies. Second, increasing interactions with international society and China's exposure to global norms of expected behavior are nevertheless leading to the country's further socialization and acceptance of greater normative commitments. Observable trends indicate that China may be moving toward a more mutually constitutive understanding of its interests and responsibilities. One may therefore view China's burgeoning global role as a great power with cautious optimism.

This article thus proceeds threefold. The first section unpacks the concepts of great power interest and responsibility by adopting an English School and constructivist theoretical framework. It then establishes the above-mentioned three-dimensional typology and spectrum as the underlying conceptual framework. The second section applies this framework to a rising China by examining ongoing shifts in China's worldview as well as the manner in which Beijing conceives its interests and responsibilities in the international system. How China's national interests and international responsibilities interplay in its foreign policy relates directly to the purpose of its power and to the global role it will adopt. The typology and spectrum can therefore be applied to illuminate the choices that China has in ascertaining the relationship between interest and responsibility. The final section operationalizes the conceptual framework with reference to China's foreign policy in Sudan, with particular attention paid to the humanitarian crisis in Darfur. Sudan is an illuminating case study as it represents a location where China's national interests and growing international responsibilities clearly intersect. Sudan is therefore a seminal test case for China because its policies and actions there will be judged by the rest of the world as representative of how China is emerging as a global power more generally.

\section{Great Power Interest and Responsibility}

A "great power," or da guo in Chinese, is distinguished by both its national power and its social role. ${ }^{1}$ Closely identified with the realist tradition of international relations, the concept of national power includes traditional attributes such as military capacity, economic strength, geography, population, national character, and national morale. ${ }^{2}$ 
A great power should have a mixture of these attributes to the extent that they facilitate its relative power over other states. The other defining characteristic of a great power evolves around the purposes for which power is wielded. To this end, a great power must reconcile its national interests with its fulfillment of international responsibilities in order for it to be respected by the other members in international society.

Despite often being viewed as ambiguous and exclusivist, ${ }^{3}$ the "national interest" is a concept that remains embedded in the international political lexicon. Realists depict the national interest as "the main signpost that helps political realism to find its way through the landscape of international politics." That description, however, renders the idea of national interest as too static or linear and fails to consider the other structures and processes that inherently comprise international relations. The English School and constructivist scholarship view the concept of national interest as more fluid and defined in relation to a state's interaction with international society. The English School argues that states should broaden national interests beyond a narrow and parochial conceptualization to embody an enlightened self-interest that takes into account the interests of other states in international society. By distinguishing between core and non-core interests, the English School broadens the notion of national interest in ways that are more cognizant of international law and morality. ${ }^{5}$

Constructivism takes this notion even further by denying that the national interest is an objective condition of the state. It seeks specifically to examine how national interests undergo processes of redefinitions. Rather than being inherent fixed properties of the state, national interests are instead shaped by norms, identity, and international society. Changing international social structures redefine state identities and worldviews, which in turn re-conceptualizes their interests and behavior. ${ }^{6}$ Proponents of the English School and constructivists thus both insist that national interests can be renegotiated through norms and wider obligations to international society.

Inherent in these two scholarly traditions is the idea that greater power heralds increased responsibilities in international society and that great powers should bear responsibilities commensurate with their power status. In his seminal work, Hedley Bull wrote that great powers are "recognized by others to have, and conceived by their own leaders and peoples to have, certain special rights and duties."7 Great powers thus carry more "moral weight" in the conduct of international affairs through the behavior they display and the standards they set. Indeed, as moral carriers of responsibility, the manner in which great powers exercise their power, whether through action or inaction, will directly influence the nature of international affairs.

The failure to enact their obligations, however, leads to the removal of great power privileges and entitlements. ${ }^{9}$ To this end, great power status comprises both a selfperception as well as a social recognition by others. As Michael Brittingham articulates, "if a state continues to act like a great power and is accepted as one by others, it may also become contested if the state no longer takes up the responsibilities associated with a great power or it is no longer clear that the state in question can live up to the role." ${ }^{10}$

This ethic of "international responsibility" has become common parlance in prescribing the foreign policy behavior of great powers. ${ }^{11}$ Under the classical balance of power system that emerged from the 1648 Treaty of Westphalia, the primary moral 
commitment expected of great powers was to abstain from the unprovoked and unilateral use of force in order to maintain international order among sovereign states. ${ }^{12}$ Particularly since the end of the Cold War, however, definitions of responsibility have evolved with the normative agenda expanding out from pluralist understandings of world order based on norms of noninterference, sovereign equality, and the nonuse of force to also include solidarist conceptualizations that emphasize issues such as human security and legitimate governance. ${ }^{13}$ This normative expansion has led to a redefinition of what it means for a great power to be "responsible." Broadly conceptualized, great power responsibility refers to the provision of public goods such as an open global economic system, international security, and the stability of the international order, as well as leadership in international institutions, peacekeeping, and other key aspects of global governance. Great power responsibility thus encompasses a more active enterprise of contributing to international order rather than simply maintaining it.

\section{Conceptualizing the Interplay between Great Power Interest and Responsibility}

In practice, policy makers and scholars have always struggled to find an appropriate balance between interest and responsibility. It is thus important to examine the relationship of, and interplay between, national interest and international responsibility in the foreign policy and behavior of great powers. To this end, a three-dimensional typology of great power interest and responsibility may be established here (see Table 1). Three categories can be seen from this typology, and can be discussed further here.

First, not all great powers may initially be willing to take on international responsibilities, and even when they do so, there may be a potential tension with their national interests. The demands of international responsibility are thus in conflict with the pursuit of national interest (Category One: Antagonistic).

Second, responsible behavior may be perceived to be in a great power's national interest in order to procure material benefits and increase international status. The desire for an international reputation as a responsible great power may lead states to be interest oriented, inclined to portray an image of responsibility for perception and symbolic purposes to placate international society and advance its international standing (Category Two: Instrumental). In this regard, it is important to recognize that international responsibility, in particular great power responsibility, is "politically as well as morally postulated.”14 A great power's failure to assume responsible behavior may cause it to forfeit its moral prestige and image in international society as a legitimate responsible great power, a point worth emphasizing as the image and reputation of a state are intangible but highly significant assets in international politics. This ethic of

TABLE 1

A THREE-DIMENSIONAL TYPOLOGY OF THE INTERPLAY BETWEEN INTEREST AND RESPONSIBILITY

\begin{tabular}{lll}
\hline Typology & $\begin{array}{c}\text { Relationship between Interest } \\
\text { and Responsibility }\end{array}$ & \multicolumn{1}{c}{$\begin{array}{c}\text { Diagrammatic } \\
\text { Representation }\end{array}$} \\
\hline Category One & Antagonistic & Interest $\longmapsto$ Responsibility \\
Category Two & Instrumental & Interest $\rightleftarrows$ Responsibility \\
Category Three & Mutually Constitutive & Interest $\rightleftarrows$ Responsibility \\
\hline
\end{tabular}


responsibility thus places certain restrictions on the exercise of raw power; unless power is exercised morally in consideration of international obligations, the image of a responsible great power is compromised.

Third, interest and responsibility may shape each other to the extent that a great power defines its national interest as being responsible and morally committed to providing public goods based on a certain sense of inherent duty. An ethically inspired foreign policy may therefore not always conflict with the pursuit of national interest because the concept of "interest" is itself not concrete and absolute. International social structures "may shape and define the preferences of actors in ways not related to internal conditions, characteristics, or functional need." ${ }^{15}$ A great power may thus be socialized by global norms and international society into new judgments about what is ethical, and thereby change its preferences and state behavior. ${ }^{16}$ The responsibility ethos is subsumed under its great power identity and foreign policy culture, and national interest is defined more in terms of being a good international citizen (Category Three: Mutually Constitutive).

Although the second and third categories result in similar outcomes - a great power portraying responsible behavior - they reflect different motivations. Great power behavior in the second category is driven primarily by an instrumental "logic of expected consequences," as opposed to an innate "logic of appropriateness" in the third category. ${ }^{17}$ Collectively, these three categories form a spectrum from which one is able to draw implications about a great power's global role (see Figure 1).

As can be seen in Figure 1, the further a great power moves to the right of the spectrum, the more optimistic one can be about its foreign policy and international behavior.

Two caveats must be acknowledged here. The first is the inherent complexities of the concepts of interest and responsibility. The second is the fact that an assessment of a great power's foreign policy will not necessarily fall neatly into one specific category of the above-established typology. Nevertheless, the model posited here can be applied to illuminate understanding for the purpose of analytical clarity. There are sufficient differences between the three categories - antagonistic, instrumental, and mutually constitutive - to discern identifiable patterns in a great power's foreign policy behavior and the future direction it is most likely to take.

Having established a conceptual framework of great power interest and responsibility, this may now be specifically applied to China's foreign policy and burgeoning global role. As one of the newest entrants in the great power club, and increasingly one of its most influential, the implications of where China might fit on the established

FIGURE 1

A SPECTRUM PROJECTING A GREAT POWER'S FUTURE GLOBAL ROLE.

Negative Implications

Positive Implications

Category One:
Antagonistic

Category Two: Instrumental 
typology and spectrum should shed some light on how it is defining its global role as a great power. The remainder of the article thus applies this framework within a wider discussion of China's worldview and interest-responsibility conceptualizations, and operationalizes it through an examination of China's foreign policy in Sudan.

\section{China's Rise as a Great Power}

As discussed earlier, "great power" conceptualization encompasses both national power and a social role. During World War II (Nationalist China) and the Cold War (the PRC), China was essentially recognized as a great power through a deliberate and conscious effort by the United States to designate its geostrategic significance. ${ }^{18}$ To the extent that China's power status was elevated at that time despite its weak material capabilities relative to the other major powers in the international system, its power was "more derivative than direct."19

More than 30 years after Deng Xiaoping initiated his economic reform policy in 1978, however, one may arguably claim that, in terms of national power, China has grown to become a great power in its own right. China is now the world's third largest economy with a 2009 World Bank economic growth forecast of 6.5 percent. ${ }^{20}$ China also announced a 14.9 percent increase in military expenditure for $2009 .{ }^{21}$ As the third largest military spender in the world, ${ }^{22}$ China's military capabilities are clearly on the rise. In addition to strengthening its military and economic power, China is also enhancing the diplomatic, cultural, and intellectual aspects of its soft power. Under $\mathrm{Hu}$ Jintao, China's foreign policy elites are increasingly engaged in various efforts to shape multilateral diplomacy in the Asia-Pacific. Since 2004, over 100 Confucius Institutes have been established around the world to promote the Chinese culture and language. ${ }^{23}$ China's education system has seen a steady increase in international student enrollments, more officials and bureaucrats from foreign governments are being trained in China, and Chinese arts and cuisine are making their way around the world. ${ }^{24}$

Thus, while China was earlier treated as a great power primarily based on social recognition of an ascribed role rather than its actual national power or the fulfillment of its international responsibilities, the issue surrounding contemporary China is not whether China has material and nonmaterial capabilities - this it has - but rather whether China is willing to undertake international responsibilities commensurate with its power status. Based on the great power equation described above, where great power is defined by its national power and social role, international attention has shifted to focus more on the latter attribute associated with intentions, responsibilities, and social recognition. To this end, an examination of China's worldview is increasingly relevant.

\section{China's Evolving Worldview}

A better appreciation of China's evolving worldview offers insight into its conceptualizations of interest, responsibility, and great power behavior. One's view of the world is heavily intertwined with an image of one's self and the ways in which history and interaction with the international system condition that identity. China has proven to be no exception. 
China's increasing interactions with the international system have resulted in fundamental attitudinal changes that have reconfigured China's perceptions of self, role, and interests. China's evolving worldview is best observed by discernible shifts in internal Chinese discourse relating to three broad aspects: international order, selfidentity, and global role. These discursive engagements will continue to unfold and deepen as China becomes more self-conscious about its rise.

To a certain extent, China remains wary of an international order from which it was previously largely excluded and where it did not partake in its initial construction. Indeed, China still "does not regard the international order as a neutral forum." ${ }^{25}$ Yet what is crucial is that China's relationship with the international order has fundamentally shifted from animosity to acquiescence. Since its integration with international society in the 1970s, China has acted primarily as a "satisfied system maintainer" rather than a "system-transforming revolutionary," ${ }^{26}$ with the agenda not of transforming it from without but of shaping it from within. China has begun to work with and define for itself a place within this primarily US-led international order by advocating the "democratization of international relations" (guoji guanxi mingzbubua). Most Chinese analysts are now promoting an "integrating and shaping” strategy rather than a revolutionary one. ${ }^{27}$ The phenomenon of China's rise has not disrupted the US-led global order, but it has set in motion certain substantial changes that are redefining and renegotiating this order.

On the issue of China's national identity, reconfiguration began when Mao Zedong declared on September 21, 1949 that China "will no longer be a nation subject to insult and humiliation. We have stood up.” ${ }^{28}$ Indeed, Mao’s symbolic speech became deeply entrenched in China's "collective national panorama" that has since shaped its foreign policy. ${ }^{29}$ Undeniably, the Century of Humiliation (bainian guochi) still occupies a prominent position in the Chinese national consciousness. In many ways, however, the world has witnessed a shift within China away from a victim mentality and toward a self-image increasingly cast as a great power.

Indeed, this self-recognition of China as a great power has emerged victorious out of the other contending notions of national identity. ${ }^{30}$ While official documents still cast China as a developing country, Chinese leaders and analysts are certainly not in denial of their country's rise and growing influence. Yan Xuetong, a prominent Chinese scholar, writes that "China's power is already large enough to disturb international political stability by shifting its strategic stance." 31 Whilst before China was trying to catch up with the other powers in terms of developing its comprehensive national power, it is now aware that it has accrued sufficient power to project a more decisive influence in international politics. Indeed, China's leaders and officials have become increasingly adept in the art of diplomacy and channeling China's interests through regional and international organizations in ways that, as some have argued, could successfully challenge US policies. ${ }^{32}$

As Beijing recognizes that great power status comprises both a self-perception as well as a conferred social recognition, however, it has also placed great emphasis on cultivating an image specifically targeted at an international audience. Although initial responses to the "China threat" (zhongguo weixie) thesis were defensive and nationalistic, ${ }^{33}$ an increasing sensitivity on the part of Beijing's leaders that China's 
rise is indeed creating anxieties in many other states has been demonstrated in recent years. China's foreign policy elites and scholars have moved beyond perceiving China as an "object" of the international system in which the world impacts on China to perceiving China as a "subject" recognizing how it itself affects the world. ${ }^{34}$ As Robert Jervis observes, "Both to interpret others' behavior and to design one's own behavior so that others will draw the desired conclusions from it, the actor must try to see the world the way the other sees it." ${ }^{35}$ It is precisely this self-awareness that has driven China's "peaceful development" (beping fazhan) discourse. To many observers of China's foreign policy, it is an indication that Beijing has begun to embrace a more sophisticated worldview. Just as the "China threat" thesis can be seen as an attempt by outsiders to securitize China's rise, the "peaceful development" image symbolizes China's effort to de-securitize it.

China now largely comprehends the damage that a "China threat" reputation could wreak by delegitimizing the country as a legitimate international actor. ${ }^{36}$ The recognition of great power status by international society is intangible but nontrivial, particularly so for a country that believes it deserves to be one. Indeed, the increasing frequency in which the expression guoji xinxiang ("international image") appears in Chinese publications demonstrates how internal discourse is attaching greater prominence to the projection of China's international image and global role. ${ }^{37}$ Seeking international legitimacy as a "responsible great power" (fuzeren da guo) has thus become a defining feature of China's foreign policy. ${ }^{38}$

At a regional level, this great power identity is manifested in China's enhanced participation and leadership in regional affairs and multilateral institutions. Whether China has envisaged a global leadership role for itself as its international influence intensifies, however, is more uncertain. At present, China has yet to articulate a longterm coherent and sustainable international strategy and global role that goes beyond the Asia-Pacific region. Beijing, however, has begun to recognize the value of understanding the roles of great powers and gaining more knowledge of their strategies. This is applied to national policy behavior by conducting regular monthly study sessions where some of the country's top scholars brief the Politburo on issues related to China's role. Its central relevance is evidenced by the airing of a 12-episode television documentary that documented the rise and fall of nine great powers since the fifteenth century. ${ }^{39}$ The Chinese Communist Party (CCP) is thus stimulating vigorous internal discourse at the governmental, academic, and societal levels. Although China may hitherto only have an inchoate conception of its global role, it is certainly seeking to understand and explore it better.

\section{"National Interest" and "International Responsibility" in Chinese Deliberations}

As with all other countries, China places a great emphasis on pursuing its national interests and addressing its security concerns. Broadly conceptualized, China's interests are similar to those of other states across time: preserving the political regime; promoting economic growth; ensuring territorial integrity; and protecting state sovereignty. Chinese theorizing on the concept of national interest is neither monolithic nor fixed. While a realpolitik strand still dominates Chinese foreign policy thinking, the liberal idealpolitik policy agenda that stresses interdependence and international institutions 
is gaining increasing visibility in Chinese discussions of national interest. ${ }^{40}$ Although there are calls to adopt more proactive policies to secure Chinese interests, "a China paying greater attention to protecting its national interest does not necessarily lead to a more difficult China." ${ }^{41}$ Chinese analysts have stressed that China should pursue its interests in line with the broader common interests of international society. ${ }^{42}$

The de facto replacement of communism with China's new dominant ideology of market socialism has meant that the legitimacy of the CCP is highly contingent on, along with nationalism, sustained economic growth. The CCP is well aware that an economic slowdown will lead to increased public discontent and social disorder, with potentially severe consequences for regime survival. To this end, the Politburo has made economic prosperity a core national interest. Its strong emphasis on domestic economic development has meant that maintaining a peaceful international environment via key policy measures is vital to China's national interest.

Territorial integrity and state sovereignty are equated primarily with keeping China united and protected against external interference. Conversely, China's official policy has maintained that it will not interfere in the internal affairs of, or impose its will on, other states. Beijing also often holds the view that international society, and particularly the United States, is unsympathetic to China's legitimate security concerns and national interests. As this article's case study will later illustrate, the above-mentioned interests apply specifically to China's foreign policy in Sudan.

The notion of responsibility (zeren) is rooted in traditional Chinese culture, primarily understood as the duties and burdens manifested in hierarchical familial or societal relationships. ${ }^{43}$ Although the term embodies connotations of morality and ethics, it is said to be heavily associated with one's positioning (dingwei), where "the Chinese sense of responsibility is very much tied to one's position of power." ${ }^{44}$ In this regard, the extent to which China will undertake international responsibilities is dependent on its rank within international society.

China's conceptualizations of responsibility have evolved over time and have become conditioned by its interactions with the international system. International responsibility in the Chinese mindset has visibly shifted from that of Revolutionary China, where Mao defined responsibility in terms of supporting international classbased struggles and transforming the international order. Upholding international order and observing Westphalian norms of noninterference and state sovereignty in contemporary international society are now more paramount.

There is a general recognition within China that simply claiming that it is a responsible power through rhetoric is not equivalent to actually acting in ways that conform to responsible great power behavior. ${ }^{45}$ There exists in the international system a growing consensus on China's changed position, where China now has a greater stake in upholding a stable international order. Indeed, as one Chinese scholar indicates, "With the rise of China would come more responsibilities. In the future, China will not only be a constructive participant but also a 'rule maker.'"46 Yet other Chinese analysts remain convinced that, "in general, the norm of international responsibility is defined by the strong." 47

This latter opinion shapes much of China's mixed reactions to the "responsible stakeholder" concept enunciated by then US Deputy Secretary of State Robert Zoellick 
in September 2005. ${ }^{48}$ As Thomas Christensen has more recently observed, the responsible stakeholder thesis is about "shaping the choices that Chinese leaders make about how to use their growing power ... encouraging China to play a greater role in international diplomacy and the international economic architecture." ${ }^{39}$ When the term first entered US political discourse, Beijing did not have a direct translation for the term, with many Chinese scholars and analysts then scrambling to interpret it. ${ }^{50}$ Although China has since accepted the term "responsible stakeholder," it has also introduced the phrase "partners of constructive cooperation" to denote a relationship of more equal footing.

The reaction by Chinese scholars to the responsible stakeholder thesis has been substantial and reflects some degree of frustration with US policy. For some, the responsible stakeholder thesis emerged as both an explicit recognition by the United States of China's development as well as an implicit recognition by the United States of its own limitations. ${ }^{51}$ For others, the concept patronizes China in that it inherently labels China as an irresponsible power once it fails to act in accordance with US interests. ${ }^{52}$ To this end, the acknowledgement of China's rise is merely a fig leaf for actually trying to "lock Beijing's position vis-à-vis Washington in the international system." ${ }^{53}$ Whilst the "China threat" proposition was one that China had to dispel, the responsible stakeholder thesis is one that China has to demonstrate. Despite establishing an entirely new benchmark, the latter thesis is perceived by several Chinese scholars as a cleverly crafted revised version of the former, and one that China cannot afford to ignore. ${ }^{54}$

Nevertheless, China's leadership seems to be taking on board Washington's invitation to be a responsible stakeholder, with Hu Jintao's "harmonious world" (bexie shijie) concept as an attempt to reconfigure and broaden China's national interests to take into account the common interests of other states. ${ }^{55}$ Beijing is doing so, for instance, by forging greater cooperation on economic, transnational, and nontraditional security issues. Various studies show how China is beginning to accept some global norms, for example in arms control, labor policy, and most recently in environmental security. ${ }^{56}$ In addition, Chinese scholors, such as Qin Yaqing and Su Changhe, reflecting constructivist approaches in international relations, argue that China has begun to internalize global norms. ${ }^{57}$

Whether China is engaging in adaptive/instrumental or cognitive/normative learning may be examined through the extent in which the ethic of responsibility becomes ingrained and internalized in its identity and thinking. Several Chinese scholars refer to international responsibilities as the "mission" of great powers but conceptualize such obligations as an instrumentalist means to dispel the "China threat" thesis and augment China's international image. ${ }^{58}$ There is growing acceptance within China of its international responsibilities, but it remains highly selective in its international obligations, choosing to undertake some more than others. ${ }^{59}$ As one Chinese scholar remarks, China needs a coherent diplomatic strategy that balances international responsibilities and cooperation with its right to ensure territorial integrity and promote domestic development. ${ }^{60}$ From this perspective, China acts responsibly to attain tangible and intangible benefits such as material gains or enhanced social status.

Yet, on the other hand, it is equally possible to envisage a China that is slowly being socialized and hence internalizing this ethic of responsibility as a growing part of its self-identity. Such trends may be seen in the writings of prominent Chinese 
scholars such as Pang Zhongying who articulate the need for China to undertake greater international responsibilities simply because it is normal behavior associated with responsible great power identity. This equates to a normative understanding of international responsibility, driven not by material calculations but by social motivations. In writing that most Chinese still subscribe to instrumentalist conceptualizations of the national interest, Pang calls for a change of thinking in the Chinese mindset. $\mathrm{He}$ asserts that a rising China must assume greater responsibility and become an "intellectual actor' in addressing questions of global governance." ${ }^{61}$ In an earlier article, Pang challenged China's limited peacekeeping role and observed that, "We often describe China as a 'firm force safeguarding world peace, not a force challenging world peace.' If this is so, then the country must actively go out and do these good things." ${ }^{2}$ That Chinese scholars have begun to discuss what it means to be a responsible great power is itself a critical development. ${ }^{63}$ Indeed, "this new discourge on international responsibility reflects an important shifting trend in China's foreign policy." ${ }^{64}$ It is indicative of the socialization process which has begun to take place within China, with a resulting impact on its international behavior.

As the discussion above underscores, there is certainly a rigorous and widening debate within China on the relationship between its interests and responsibilities. While China under Mao "did not feel obliged to take any social responsibility to an international society of which it was not regarded part of and in which its legitimacy was tenaciously denied" transformation. Chinese deliberations on the interplay between its national interest and international responsibility now largely encompass a combination of both instrumental and mutually constitutive understandings (Categories Two and Three respectively). Yet how is this being translated to its foreign policy? It is thus useful to scrutinize more closely the interplay between national interest and international responsibility in China's foreign policy, a relationship that can be discussed with respect to Sudan.

\section{China's Interest-Responsibility Nexus in Sudan}

China's foreign policy in Sudan is illuminating as it represents a locale where China's national interests and the demands of international responsibility intersect. By investigating whether the interplay between China's interests and responsibilities in its Sudanese foreign policy is antagonistic, instrumental, or mutually constitutive, an informed assessment of China's burgeoning global role can be made. As the analysis below intimates, China's foreign policy in Sudan falls mainly in the second category (instrumental) of the typology. Nascent observations indicate, however, that the potential for China to progressively move toward a more mutually constitutive conceptualization of its interests and responsibilities (the third category) is relatively strong.

Both countries have maintained good relations since 1959, when Sudan became the fourth African country to recognize the PRC. The Friendship Hall in Khartoum, built by the Chinese to symbolize friendly bilateral ties in the 1970 s, serves as a reminder to many Sudanese of China's positive contributions during that period. ${ }^{66}$ China's contemporary relationship with Sudan is thus built on the foundation of previously established good relations. What is striking, however, is the extent to which China's expanding economic, military, and political footprint has become increasingly visible 
in Sudan. China's interests in Sudan are driven by its growing energy needs and access to Sudanese arms markets, and are largely governed by the principles of state sovereignty and noninterference. Those interests, however, are increasingly juxtaposed against demands by the international community for it to fulfill its international responsibilities. The controversy over China's relations with Sudan arises from international concerns that China's policies with a pariah state are undermining global human rights norms, aid conditionality measures, and global governance, particularly in light of the ongoing humanitarian crisis in Darfur. ${ }^{67}$

Since becoming a net oil importer in 1993, securing energy supplies has become an integral part of China's national interest. The Chinese leadership is fully cognizant of the importance of energy to sustain their country's economic growth and the legitimacy of the CCP. China's oil relationship with Sudan, which began in 1994, may be framed within this context. ${ }^{68}$ Since 1996, its investments in Sudan's oil industry and related infrastructure development have amounted to more than US\$15 billion. ${ }^{69}$ The China National Petroleum Corporation (CNPC) currently dominates Sudan's oil industry, with a 40 percent stake in the Greater Nile Petroleum Operation Company, a 41 percent stake in the Petrodar Operating Company, a 35 percent stake in the Red Sea Petroleum Operating Company, and an almost exclusive ownership of 95 percent in Block 6. ${ }^{70}$ Before being overtaken by Angola, Sudan was China's chief African oil supplier, supplying 9 percent of China's total oil imports in 2002. Sudan has therefore "served as a bridgehead for China into the African oil market and a stepping stone for its ambitions to grow within the global oil industry." ${ }^{\prime 1}$

China's bilateral military relationship with Sudan is similarly significant. Since 2002, high-level meetings between military officials from the Sudan Armed Forces (SAF) and the People's Liberation Army have taken place. In 2003, China's small arms sales to Khartoum amounted to approximately US\$3 million. That figure, however, increased to over US\$55 million in 2006. ${ }^{72}$ China's arms sales to Sudan have led one commentator to assert that "the Sudanese army resembles a second Chinese Liberation Army." ${ }^{73}$ The latest Pentagon report on China's military power indicates that 90 percent of Sudan's small arms acquisitions during 2004 and 2006 were procured from China. ${ }^{74}$

The principles of state sovereignty, territorial integrity, and noninterference in internal affairs have come to characterize China's relations with Sudan and other countries on the African continent. China's noninterference principle gives it an advantage in obtaining energy supplies from countries that Western oil companies are prohibited from exploiting and has become an enabling factor in intensifying its relations with African governments. Beijing's noninterference stance was perhaps spelled out most clearly in a 2004 statement by then Deputy Foreign Minister Zhou Wenzhong when he noted that, "Business is business. We try to separate politics from business ... The internal situation in the Sudan is an internal affair, and we are not in a position to impose upon them." 75

Yet even if one detaches the issue of China's oil interests and noninterference in Sudan, China will remain vociferously opposed to any form of international intervention in Darfur without the consent of Khartoum. This is because sovereignty and territorial integrity remain for China the central organizing principles of international relations and represent two core Chinese national interests - hardly surprising considering how 
China's historical memory as a semi-colonial subject in the Century of Humiliation still remains in the contemporary national mindset. China is equally wary that human rights issues could be used as a moral pretext for intervention and regime change; such issues hit especially close to home with respect to Tibet and Xinjiang.

In the United Nations Security Council (UNSC), China has maintained a no-sanctions policy on Sudan. Draft resolutions that included a compliance enforcement mechanism have been significantly modified. Although UNSC Resolution 1556 was adopted on July 30, 2004 under a Chapter VII mandate of the UN Charter and demanded the disarmament of the Janjaweed by the government of Sudan, it merely called for the consideration of "further actions" in the event of noncompliance. China, along with Algeria, Brazil, and the United States, abstained in UNSC Resolution 1593 that referred Darfur to the International Criminal Court.

Undoubtedly, the humanitarian crisis in Darfur has been a diplomatic challenge for China, both in articulating its foreign policy with Sudan and in the impact that Darfur has had on its international image. China's interests are seen by many as propping up an egregious regime and providing Khartoum with diplomatic insulation from the UNSC with its veto power. Oil revenues continue to underwrite Khartoum's counterinsurgency campaign in Darfur. In addition, reports indicate that arms procured from China have been used by the Sudanese government to carry out massive human rights atrocities in Darfur. ${ }^{76}$ The SAF has also conducted aerial bombings of oil-rich areas and used CNPC oil facilities as a base to forcibly displace civilians in order to clear the land for oil exploration and expansion. ${ }^{77}$ This in turn undermines attempts by the United Nations to advance a more solidarist world agenda through effective global governance. In the eyes of the international community, China's intimate dealings with the government of Sudan should be translated into political influence and leverage to seriously pressure Khartoum into pushing for a comprehensive political solution.

In recent years, however, China has demonstrated an increased willingness to align itself with the international community and diplomatically engage Khartoum to resolve the crisis in Darfur. Speaking at a press conference with Tony Blair in September 2006, Premier Wen Jiabao stressed that, "China is very much concerned about the stability in Darfur." $\mathrm{Hu}$ Jintao’s grandiose eight-nation African tour in February 2007 included granting Sudan an interest-free loan of US\$13 million for the building of a new presidential palace, thus keeping very much in line with strengthening its economic ties. Yet Hu reportedly also told Sudanese President Omar Hassan al-Bashir to adopt more earnest measures to engage the non-signatories of the 2006 Darfur Peace Agreement in peace talks. ${ }^{79}$ In addition, $\mathrm{Hu}$ has outlined four key principles in seeking a resolution in Darfur and has engaged Bashir in behind-the-scenes diplomacy via private phone conversations and letters. ${ }^{80}$

Although China in principle still places a high premium on sovereignty and nonintervention, in practice the debates in Beijing reflect a shift from an obdurate defense of the noninterference principle to the preconditions for legitimate international intervention. ${ }^{81}$ Typifying the thinking behind this revised posture is the observation of Yan Xuetong, an influential Chinese scholar, who has written that, "sovereignty is not synonymous with national interests anymore; rather it should be subject to overall national interests, not protected at all costs." 82 
With a view of the United Nations as the legitimate authority in international affairs, China no longer eschews intervention but instead accepts interventions that are conducted under UN auspices and which have obtained the consent of the state in question. Over the last three decades, China's position on peacekeeping has shifted from "principled opposition [and] nonparticipation" to "support and situation-specific participation." ${ }^{\prime 3}$ China is now the largest peacekeeping contributor among the five permanent members of the UNSC, believing that peacekeeping is a natural extension of its growing international obligations and global role. China's more flexible interpretation of sovereignty now reflects a mélange of traditional Westphalian conceptualizations and new norms concerning the "responsibility to protect" and the legitimacy of humanitarian intervention. ${ }^{84}$

China has applied consistent diplomatic pressure on the Sudanese government. When Khartoum voiced objections over the second phase of the "Annan Plan" that endorsed the deployment of a UN Heavy Support Package, ${ }^{85}$ State Councilor Tang Jiaxuan met with visiting Presidential Assistant Nafie Ali Nafie on March 29, 2007 and expressed hope that Sudan would display greater flexibility and improve the humanitarian situation in Darfur. ${ }^{86}$ This Chinese position was reinforced during the dispatch of Assistant Foreign Minister Zhai Jun to Sudan in early April 2007, where he became China's first senior official to visit internally displaced persons' camps in Darfur and obtain a better understanding of current realities. Khartoum's subsequent acceptance of the UN Heavy Support Package was largely credited to the talks held between Zhai and Bashir. Furthermore, Liu Guijin was appointed China's Special Envoy to Darfur in May 2007. Despite acknowledging differences in their methods for seeking peace in Darfur, Liu has commented that China is "ready to cooperate sincerely with the West on Darfur." $\$ 7$

Under China's presidency, the UNSC passed Resolution 1769 on July 31, 2007 authorizing the establishment of a 26,000-troop hybrid operation by the United Nations-African Union Mission in Darfur (UNAMID). Prior to, and particularly since, the passing of the resolution, top Chinese officials have been working with Khartoum to discuss the deployment of UNAMID peacekeepers, the first time since being on the UNSC that China has sought to convince a sovereign country to allow a UN peacekeeping force on its soil. ${ }^{88}$

\section{A Moral-Free Foreign Policy? Assessing the Interplay of China's Interests and Responsibilities in Sudan}

The China-Sudan relationship has become a significant lens through which one can assess the interplay of China's interests and responsibilities, and the implications for its burgeoning global role. Rather than extrapolating China's behavior merely from one or two episodes of its foreign policy dealings, it is wiser to examine China's relationship with Sudan over time. This allows for a more complete and nuanced understanding that better captures China's evolving foreign policy. Observable trends indicate both changes and continuities in Beijing's relationship with Sudan. Three fundamental elements continue to highlight the pursuit of China's national interests, and when combined with the changes in its foreign policy approach, demonstrate the largely instrumental nature of its interest-responsibility nexus in Sudan. 
First, China has sought to consolidate its economic and military ties to the regime. To this end, a fundamental incongruity exists between China's diplomatic endeavors with respect to Darfur and its own economic and military bilateral relationship with Sudan. There is a widespread belief in China that the Darfur conflict stems largely from abject poverty and a lack of economic development, and that it is thus unfair to link China's economic and military dealings with the government of Sudan to the humanitarian crisis in Darfur. ${ }^{89}$ Not only do such beliefs depoliticize the historical and political dimensions of the conflict, they also fail to recognize how China is complicit in Darfur. In a recent interview, Liu Guijin commented that Sino-Sudanese cooperation "is conducive to the solution of Darfur ... The Sudanese government has used oil revenue to spur national development including the development of [the] Darfur region." 90

Such remarks are particularly significant since they come from China's major diplomatic figure in the region. They stand in stark contrast to accusations that China is propping up the Sudanese regime and financing the crackdown in Darfur through its oil investments and arms sales. Even as China undertook a more constructive role and increased diplomatic pressure on Khartoum, it simultaneously expanded economic and military bilateral ties. This captures the full extent to which China continues to disassociate its economic and military dealings with the ongoing conflict and defend its economic and military interests. Comments by Chinese scholars that, "nation building is a difficult process," and that, "the international community has to give Sudan some time to solve this problem," 91 offer a similarly tenuous justification of China's hands-off policy.

Second, China has maintained the position that a resolution to Darfur must come from engagement and negotiation, urging the West to recognize and respect Khartoum as the legitimate government rather than implement sanctions on or diplomatically isolate the regime. Unlike the West's usual “carrot and stick" approach, the distinguishing characteristic of China's diplomacy has been its heavy emphasis on respect and equal dialogue; indeed, "China addressed Khartoum without carrying sticks." 92

Third, China has not wavered in arguing that state consent must be sought before any UN intervention is adopted. Given the selectivity of humanitarian interventions and the inconsistency of the application of the "responsibility to protect," China's insistence on Khartoum's consent to UNAMID has at least meant that its deployment is deemed legitimate both by the international community and by the government of Sudan. The war in Iraq continues to demonstrate the complexities and negative consequences of unilateral interventions sanctioned neither by the United Nations nor the state in question. Such an intervention in Sudan could be equally disastrous without necessarily leading to any improvement over the current situation now.

Yet even as it has protected Sudan's sovereignty in the United Nations, China has urged Khartoum to accept UNAMID troops on Sudanese territory and has registered its displeasure and impatience with Khartoum's intransigence. In doing so, Beijing has demonstrated that it is no longer willing to give unqualified support to the Sudanese regime vis-à-vis its traditional principle of noninterference. China's diplomatic interventions underscore its increasing participation in the rules of engagement of the international community. This evolutionary but significant policy shift indicates that China is undertaking more global responsibility by seeking a resolution to the Darfur conflict, albeit driven primarily by self-interested motivations and instrumental calculations. 
These motivations arise from having experienced firsthand the insidious effects of increasing instability in Darfur on its oil interests, with its oil fields and workers targeted by rebel groups and with the Darfur region hostile to the Chinese peacekeeping force that has been deployed there. Indeed, China is facing increasing discontent and aggression from the rebel groups who view its relations with Khartoum as perpetuating the conflict and have warned China to withdraw its support for Khartoum. Border incursions by Darfur rebels into neighboring Chad and escalating tensions between the Chadian and Sudanese governments are similarly worrying for a China that wants to protect its energy interests there. Beijing is also learning that a strict hands-off approach via its noninterference principle is no longer tenable, particularly in light of increasing discontent amongst the general public in Sudan and other African states. Conversely, Chinese policymakers are also aware of how their evolving conception of the noninterference principle may not sit well for a country that stresses noninterference and south-south solidarity as a hallmark of its African policy.

Either way, China is growing increasingly cognizant of the complexities and potential liabilities of its African engagement. Indeed, it is discovering the unanticipated risks of its relationship with Sudan and the damage that Darfur has done to its image abroad. Several Chinese scholars in Beijing's leading think tanks and universities have even gone so far as to assert that China's state-owned oil companies have "hijacked" China's foreign policy in Sudan. ${ }^{93}$ Intense international opprobrium has emerged at a time when China increasingly wants to portray an international image of mature sophistication, and the Chinese have shown that they are not impervious to international pressure, particularly when their international reputation as a responsible great power is at stake.

The conceptual interplay between China's interests and responsibilities is therefore moving most generally toward mirroring the second category (instrumental) of the previously established typology. China is selectively fulfilling its international responsibilities largely to serve its national interests, even if these interests are now conceptualized less parochially than before. By paying equal attention to its demand for oil, its international reputation, the risks of instability in Darfur to its vested interests, and its wider relations with other African countries, as well as the growing demands for it to exercise international responsibility, China has "succeeded in avoiding tough choices between external expectations and its proper standards and interests." "In doing so, China seems to have calibrated a win-win situation with its adroit diplomatic maneuverings. It has appeased some of the international community's demands and displayed some willingness to exercise its responsibilities. At the same time, China has ensured that its privileged relationship with Sudan is not jeopardized, its interests are secured, and its international reputation is enhanced. China is thus both gaining moral credibility through its efforts in Darfur and reaping the benefits from its strengthened relationship with Khartoum.

Whether such a policy can be maintained over a long term and carried across to other issue areas remains questionable. China is clearly thinking about assuming a wider global role with greater responsibilities, and this is a step in the right direction. Such contemplations are not yet, however, being translated into cogent and consistent Chinese policies across the board. China is still seemingly finding its way and 
testing the waters. China's foreign policy in Sudan demonstrates that it is driven more by an instrumental "logic of expected consequences" than by an intrinsic "logic of appropriateness." Yet its exposure in Darfur to what the international community expects of China as a great power is slowly but surely providing feedback into a socialization process. China is learning and forming opinions about the appropriate behavior of a responsible great power, in particular a recognized one. This in turn generates intensified Chinese conceptualizations toward a more mutually constitutive relationship between interest and responsibility (the third category of the established typology). As China moves further right along the spectrum from the second to the third category of the typology, one may view China's great power role with cautious optimism.

\section{Conclusion}

China's historical experience during the Century of Humiliation still remains in the contemporary Chinese mindset. This means that China may at times fall back on its traditional identity as a developing country. Commensurate with the first category of the three-dimensional typology, this is a China that views international responsibilities as often incompatible with the pursuit of its national interests and adopts a defensive and largely reactionary foreign policy. The dominant self-identity in China, however, is one of China as a great power. As a prestige-seeking state, China's international image is of utmost importance to Beijing. The projection of a responsible great power image by selectively undertaking its international obligations therefore serves the purpose of its national interests. As the analysis of its foreign policy in Sudan demonstrates, China is for the most part reconciling its interests and responsibilities in an instrumental manner, congruent with the second category of the established typology. China has recalibrated its foreign policy based on international pressure, a re-evaluation of its national interests and its aspiration to be recognized as a responsible great power. In addition, China is highly cognizant of its growing influence and how this can be utilized to project and advance its national interests. It is clear that China is thinking about its role in more global terms, even if this has yet to translate into long-term cogent policies that articulate a coherent global role. Yet China's increasing interactions with international society have resulted in significant shifts in its worldview, as well as in how China is conceiving its interests and responsibilities in a more mutually constitutive fashion. This falls within the third category of the typology. This may well in turn lead to further socialization and greater normative commitments.

Taken collectively, one may ascertain that the interplay between China's pursuit of national interest and the fulfillment of its international responsibilities is best characterized as instrumental. China is undertaking its obligations to international society but is doing so pragmatically, understanding the trade-offs to be made in foreign policy making. A rising China is one gravitating toward greater notions of responsibility, albeit instrumentally. Yet China has also broadened and renegotiated its conceptualization of national interests in line with perceptions of its international responsibilities. China's evolving worldview and greater acquiescence of international order are viewed by many as a welcome development. In this regard, observable trends indicate that, in terms of the conceptual interplay between interest and responsibility, China 
will most likely move from its current middle position on the spectrum (instrumental) toward the right (mutually constitutive) rather than to the left (antagonistic). Whilst examining how far China still might have to develop in becoming a truly responsible great power, it is perhaps equally important to acknowledge from a historical perspective how far China has already come. In this context, China's journey remains unfinished, but it has been one with many positive changes. A considered judgment about China's future international behavior and burgeoning global role thus yields cautious optimism.

\section{NOTES}

1. Barry Buzan, The United States and the Great Powers: World Politics in the Twenty-First Century (Cambridge, U.K.: Polity Press, 2004), p. 59.

2. These elements, along with natural resources, the quality of government, and the quality of diplomacy, are identified by classical realist Hans Morgenthau. According to John Mearsheimer, a leading proponent of offensive realism, great powers are fundamentally distinguished by their military capabilities in relation to others, where a state becomes a great power when it is able to stage but not necessarily win a conventional war with the existing predominant power. See Hans J. Morgenthau, Politics among Nations: The Struggle for Power and Peace, 4th ed. (New York: Alfred A. Knopf, 1967), chapter 9; John J. Mearsheimer, The Tragedy of Great Power Politics (New York: W. W. Norton and Company, 2001), p. 5.

3. See Scott Burchill, The National Interest in International Relations Theory (New York: Palgrave Macmillan, 2005), pp. 8, 206; W. David Clinton, The Two Faces of National Interest (Baton Rouge, LA: Louisiana State University Press, 1994), pp. 21-49.

4. Morgenthau, Politics among Nations, p. 5.

5. Burchill, The National Interest in International Relations Theory, pp. 152-184.

6. Martha Finnemore, National Interests in International Society (Ithaca, NY: Cornell University Press, 1996), pp. $1-15$.

7. Hedley Bull, The Anarchical Society: A Study of Order in World Politics, 3rd ed. (Hampshire, U.K.: Palgrave, 2002), p. 196. See also Inis L. Claude, Jr., "The Common Defense and Great Power Responsibilities," Political Science Quarterly Vol. 101, No. 5 (1986), p. 724.

8. Cathal J. Nolan, "The Evolution of Great Power Rights and Responsibilities," in Cathal J. Nolan, ed., Power and Responsibility in World Affairs: Reformation versus Transformation (Westport, CT: Praeger Publishers, 2004), p. 15.

9. Hedley Bull, “The Great Irresponsibles? The United States, the Soviet Union, and World Order," International Journal Vol. 35, No. 3 (Summer 1980), p. 446.

10. Michael Alan Brittingham, "China’s Contested Rise: Sino-US Relations and the Social Construction of Great Power Status," in Guo Sujian and Hua Shiping, eds., New Dimensions of Chinese Foreign Policy (Lanham, MD: Lexington Books, 2007), p. 92.

11. This article maintains that although the notion of responsibility is inter-subjective at an abstract level, it remains heavily contested at a definitional level and lends itself to myriad interpretations about what it actually means to be "responsible." Exploring the notion of international responsibility reveals deep ambiguity over what responsibility entails, how it is being defined and redefined in political discourses over time, who is engaged in this process, and for what purposes. Whether a country is deemed responsible or not is often largely dependent on who is making the measured judgment. Indeed, these fundamental ambiguities, or what may be termed the "responsibility problématique," represent the crux of the conceptual debate on international responsibility. Nevertheless, one may identify a dominant, albeit primarily Western conceptualization of great power responsibility, even if the parameters are contested and tensions remain.

12. Nolan, "The Evolution of Great Power Rights and Responsibilities," pp. 18-19.

13. Nolan, "The Evolution of Great Power Rights and Responsibilities," pp. 29-30; Rosemary Foot, "Chinese Power and the Idea of a Responsible State," China Journal No. 45 (January 2001), p. 9.

14. Zhang Yongjin and Greg Austin, "China and the Responsibility of Power," in Zhang Yongjin and Greg Austin, eds., Power and Responsibility in Chinese Foreign Policy (Canberra, Australia: Asia Pacific Press, 2001), p. 5.

15. Finnemore, National Interests in International Society, p. 22.

16. Finnemore, National Interests in International Society, pp. 2-3.

17. A "logic of expected consequences" may be conceived as utilitarian calculations of interest and expected outcomes corresponding to certain state actions and behavior. On the other hand, a "logic of appropriateness" refers to state actions based on a belief about what is appropriate and right and is largely associated with a state's identity. These terms are extracted from James G. March and Johan P. Olsen, "The Institutional Dynamics of International Political Orders," International Organization Vol. 52, No. 4 (Autumn 1998), pp. 949-951.

18. See Brittingham, "China’s Contested Rise: Sino-US Relations and the Social Construction of Great Power Status," pp. 94-99; Avery Goldstein, Rising to the Challenge: China's Grand Strategy and International Security (Stanford, CA: Stanford University Press, 2005), pp. 69-70. 
19. Cheng Sijin, “Gauging China’s Capabilities and Intentions under Deng and Mao,” in Cathal J. Nolan, ed., Power and Responsibility in World Affairs: Reformation versus Transformation (Westport, CT: Praeger Publishers, 2004), p. 110.

20. The World Bank, China Quarterly Update, March 2009, p. 1. Available at http://www.worldbank.org/china; The International Monetary Fund, World Economic Outlook Database, April 2009. Available at http:// www.imf.org

21. “China to Boost Military Spending," BBC News, March 4, 2009.

22. Stockholm International Peace Research Institute (SIPRI), SIPRI Yearbook 2008: Armaments, Disarmaments, and International Security, Chapter 5 Military Expenditure Summary. Available at http://yearbook2008.sipri.org

23. Jocelyn Chey, “The Gentle Dragon: China’s 'Charm Offensive,' Through Confucius Institutes, Wins Allies around the Globe,” Yale Global Online, November 29, 2007.

24. See Joshua Kurlantzick, Charm Offensive: How China's Soft Power is Transforming the World (Victoria, Australia: Melbourne University Press, 2007), pp. 67-71, 116-121; Bates Gill and Yanzhong Huang, "Sources and Limits of Chinese 'Soft Power,'” Survival Vol. 48, No. 2 (Summer 2006), pp. 17-19.

25. Rana Mitter, “An Uneasy Engagement: Chinese Ideas of Global Order and Justice in Historical Perspective,” in Rosemary Foot, John Lewis Gaddis, and Andrew Hurrell, eds., Order and Justice in International Relations (Oxford: Oxford University Press, 2003), p. 221.

26. Samuel S. Kim, "China and the United Nations," in Elizabeth Economy and Michael Oksenberg, eds., China Joins the World: Progress and Prospects (New York: Council on Foreign Relations Inc., 1999), p. 80.

27. Tang Shiping, "Projecting China's Foreign Policy: Determining Factors and Scenarios," in Jae Ho Chung, ed., Charting China's Future: Political, Social, and International Dimensions (Lanham, MD: Rowman \& Littlefield Publishers Inc., 2006), p. 135.

28. "Opening address by Mao Zedong, Chairman of the Chinese Communist Party, at the First Plenary Session of the Chinese People's Political Consultative Conference," September 21, 1949. Available at http:// www.international.ucla.edu

29. David Scott, China Stands Up: The PRC and the International System (London: Routledge, 2007), p. 1.

30. Gilbert Rozman, “China's Quest for Great Power Identity,” Orbis Vol. 43, No. 3 (Summer 1999), p. 385.

31. Yan Xuetong, "The Rise of China and Its Power Status," Chinese Journal of International Politics Vol. 1, No. 1 (2006), p. 32.

32. See for instance, Evan S. Medeiros and M. Taylor Fravel, “China’s New Diplomacy,” Foreign Affairs Vol. 82, No. 6 (November/December 2003), pp. 22-35.

33. “Li Zhaoxing Refutes 'China Threat' Theory,” People's Daily, December 29, 2000; “'China Threat' Theory Groundless,” China Daily, June 28, 2002.

34. See for instance, Yu Xintian, "Harmonious World and China's Path for Peaceful Development," International Review Vol. 45 (Winter 2006), pp. 1-21. This object/subject analogy is drawn from Bates Gill, who makes a similar point but distinguishes between China as an "object” and China as a "very large object." See Bates Gill, “Discussion of 'China: A Responsible Great Power,'” Journal of Contemporary China Vol. 10, No. 26 (2001), p. 30.

35. Robert Jervis, Perception and Misperception in International Politics (Princeton, NJ: Princeton University Press, 1976), p. 409.

36. Yong Deng, "Reputation and the Security Dilemma: China Reacts to the 'China Threat' Theory," in Alastair Iain Johnston and Robert S. Ross, eds., New Directions in the Study of China's Foreign Policy (Stanford, CA: Stanford University Press, 2006), pp. 187-214.

37. Raviprasad Narayanan, "The Chinese Discourse on the 'Rise of China," Strategic Analysis Vol. 31, No. 4 (July 2007), p. 655.

38. The PRC will, at times, however, shy away from using the term "great power" and instead deplay the prefix "responsible" in connection to less threatening terms. In such a vein, PRC Foreign Ministers talk of how "China conveys an image of a responsible big country" (Tang Jiaxuan), with public diplomacy language employed to "build up an image of a responsible big country" (Yang Jiechi). See Tang Jiaxuan, "World Situation and China's Diplomacy," Ministry of Foreign Affairs of the People's Republic of China, December 25, 2001. Available at http://www.fmprc.gov.cn/eng; "Foreign Minister Yang Jiechi Accepts an Exclusive Interview by People's Daily at the End of the Year," People's Daily, December 24, 2007.

39. The study sessions are conducted under the leadership of $\mathrm{Hu}$ Jintao and focus on issues such as the rise and fall of great powers, China as a regional power, and crisis management. With the themes later disseminated to the wider public, such sessions are unprecedented in that Mao, Deng Xiaoping, and Jiang Zemin were either averse to such consultations or conducted them only discreetly. The documentary series in late 2006 was an attempt to offer a more nuanced perspective that focused on the positive contribution of great powers, a marked difference from the previous reliance on middle school textbooks to convey CCP thought to the Chinese masses and which branded great powers as "imperialists." See Howard W. French, "China Opens a Window on the Really Big Ideas," New York Times, June 2, 2004 ; and Joseph Kahn, "China, Shy Giant, Shows Signs of Shedding Its False Modesty," New York Times, December 9, 2006.

40. Yong Deng, “The Chinese Conception of National Interests in International Relations," The China Quarterly Vol. 154 (June 1998), p. 329.

41. Yong Deng and Sherry Gray, "Introduction: Growing Pains - China Debates Its International Future," Journal of Contemporary China Vol. 10, No. 26 (2001), p. 10. 


\section{Asian Security}

42. Shi Yinhong, "The Rising China: Essential Disposition, Secular Grand Strategy, and Current Prime Problems,” Sasakawa Peace Foundation USA Seminar, February 12, 2002. Available at http://www.spfusa.org

43. Gerald Chan, China's Compliance in Global Affairs: Trade, Arms Control, Environmental Protection, Human Rights (Singapore: World Scientific Publishing, 2006), p. 12.

44. Chan, China's Compliance in Global Affairs, pp. 15-16.

45. See for instance, Zhang Ruowu, “On China’s Role,” Beijing Review Vol. 46, No. 52 (December 25, 2005$)$, p. 2.

46. Ruan Zongze, "What Are the Implications of China's Peaceful Rise to the World?" IRChina. Available at http://www.irchina.org/en

47. Yan Xuetong, “The Rise of China in Chinese Eyes," Journal of Contemporary China Vol. 10, No. 26 (2001), p. 37.

48. Robert B. Zoellick, "Whither China: From Membership to Responsibility?” Remarks to National Committee on US-China Relations, New York, September 21, 2005. Available at http://www.state.gov

49. Thomas J. Christensen, “Shaping China's Global Choices Through Diplomacy,” Statement before the US-China Economic and Security Review Commission, US Department of State, Washington DC, March 18, 2008. Available at http://www.state.gov

50. Neil King, Jr. and Jason Dean, "Untranslatable Word in US Aide's Speech Leaves Beijing Baffled," The Wall Street Journal, December 7, 2005.

51. Wu Xinbo, "How to Face the Internationalized Sino-US Relations," People's Daily, February 11, 2006.

52. Yang Wenchang, "Time to Correct Those Western Misconceptions," China Daily, July 9, 2007; Joshua Eisenman and Devin T. Stewart, “Can 'Responsible Stakeholder' Hold?” Policy Innovations, December 12, 2007.

53. Eisenman and Stewart, "Can 'Responsible Stakeholder' Hold?"

54. See for instance, Yuan Peng, "Sino-American Relations: New Changes and New Challenges," Australian Journal of International Affairs Vol. 61, No. 1 (March 2007), p. 109.

55. See Yu Xintian, "Harmonious World and China's Path for Peaceful Development," p. 10.

56. Such adjustments are discussed by Alastair Iain Johnston and Paul Evans, "China's Engagement with Multilateral Security Institutions," in Alastair Iain Johnston and Robert S. Ross, eds., Engaging China: The Management of an Emerging Power (London: Routledge, 1999), pp. 235-272; Ann Kent, Beyond Compliance: China, International Organizations, and Global Security (Stanford, CA: Stanford University Press, 2007); Stephanie Kleine-Ahlbrandt and Andrew Small, "China's New Dictatorship Diplomacy: Is Beijing Parting with Pariahs?” Foreign Affairs Vol. 87, No. 1 (January/February 2008), pp. 38-56. The latter includes a discussion of Sudan.

57. Qin Yaqing, "Nation Identity, Strategic Culture and Security Interests: Three Hypotheses on Interaction between China and International Society," SIIS Journal No. 2 (2003). Available at http://www.allacademic.com

58. Wang Yizhou, "China's State Security in a Time of Peaceful Development: A New Issue on Research Agenda," China E World Economy Vol. 15, No. 1 (2007), pp. 84-85.

59. Zhang Yunling and Tang Shiping, "China's Regional Strategy," in David Shambaugh, ed., Power Shift: China and Asia's New Dynamics (Berkeley, CA: University of California Press, 2005), p. 50.

60. Wang Yizhou, “China's Diplomacy for the Twenty-First Century: Balance among Three Demands.” IRChina. Available at http://www.irchina.org/en

61. Pang Zhongying, "China, My China,” The National Interest Vol. 83 (Spring 2006), p. 10.

62. Pang Zhongying, "Some Points on Understanding China's International Environment," In the National Interest, October 16, 2002. Available at http://www.inthenationalinterest.com

63. See also Xia Liping, "China: A Responsible Great Power," Journal of Contemporary China Vol. 10, No. 26 (2001), pp. 17-25.

64. Chen Zhimin, "International Responsibility and China's Foreign Policy,” in Masafumi Iida, ed., China's Shift: Global Strategy of the Rising Power (Tokyo: National Institute for Defense Studies, 2009), p. 7.

65. Zhang and Austin, "China and the Responsibility of Power," p. 6.

66. Daniel Large, "Sudan's Foreign Relations with Asia: China and the Politics of 'Looking East," Institute for Security Studies Occasional Paper No. 158 (February 2008), p. 2.

67. Since the latest manifestation of the Darfur conflict began in February 2003, approximately 300,000 people have been killed, with more than 2.7 million internally displaced persons and an estimated 260,000 refugees taking shelter in neighboring Chad.

68. The China-Sudan energy relationship began two years after Chevron sold its oil concessions and left Sudan. It was a mutually beneficial relationship as Sudan, diplomatically isolated by the West due to its terrorist links, required investment to develop its oil industry. China, on the other hand, was both searching for oil opportunities and seeking to make its national oil companies more globally competitive in a Western-dominated oil market. See Daniel Large, “Arms, Oil, and Darfur,” Small Arms Survey, Sudan Issue Brief, No. 7 (July 2007), p. 2. Available at http://www.smallarmssurvey.org

69. Chris Alden, China in Africa (London: Zed Books, 2007), p. 61.

70. Block 6 is the oil area that straddles western Kordofan and south Darfur. Large, “Arms, Oil, and Darfur," p. 2.

71. Large, “Arms, Oil, and Darfur," p. 2.

72. Human Rights First, Investing in Tragedy: China's Money, Arms, and Politics in Sudan, March 2008, pp. 11-12. Available at http://www.humanrightsfirst.org

73. Andrei Chang, "China Selling Advanced Weapons to Sudan," UPI Asia Online, February 15, 2008.

74. US Department of Defense, Military Power of the People's Republic of China 2009, March 2009, p. 58. Available at http://www.defenselink.mil 
75. Cited in Howard W. French, "China in Africa: All Trade, with No Political Baggage," New York Times, August 8, 2004.

76. See for instance, Amnesty International, "Sudan/China: Appeal by Amnesty International to the Chinese Government on the Occasion of the China-Africa Summit for Development and Cooperation," November 1, 2006. Available at http://www.amnesty.org; Hilary Andersson, "China is Fueling War in Darfur," $B B C$ News, July 13, 2008.

77. Ian Taylor, "China's Oil Diplomacy in Africa," International Affairs Vol. 82, No. 5 (2006), p. 950; Daniel Large, "China and the Contradiction of 'Non-Interference' in Sudan," Review of African Political Economy Vol. 35, No. 1 (2008), p. 97.

78. See "Press Conference with China’s Premier Wen Jiabao," 10 Downing Street, September 13, 2006. Available at http://www.number-10.gov.uk

79. Alfred De Montesquiou, “China’s Hu Presses Sudan for Progress on Darfur,” Washington Post, February 3, 2007.

80. These four principles are: respecting Sudan's sovereignty and territorial integrity; seeking a peaceful resolution through dialogue based on equality; strengthening the role and capacity of the African Union and the United Nations; and improving the living conditions of local people in Darfur. "Hu Puts Forward Principle on Darfur Issue," China Daily, February 5, 2007; “Diplomat Views China's Role on Darfur Issues, Stresses 'Even-Handedness,”’ BBC News, June 2, 2007.

81. Kleine-Ahlbrandt and Small, “China’s New Dictatorship Diplomacy: Is Beijing Parting with Pariahs?” p. 39.

82. Cited in Bates Gill and James Reilly, "Sovereignty, Intervention, and Peacekeeping: The View from Beijing," Survival Vol. 42, No. 3 (Autumn 2000), p. 43.

83. Samuel S. Kim, "Chinese Foreign Policy Faces Globalization Challenges," in Alastair Iain Johnston and Robert S. Ross, eds., New Directions in the Study of China's Foreign Policy (Stanford, CA: Stanford University Press, 2006), p. 296.

84. Allen Carlson, "More Than Just Saying No: China's Evolving Approach to Sovereignty and Intervention since Tiananmen," in Alastair Iain Johnston and Robert S. Ross, eds., New Directions in the Study of China's Foreign Policy (Stanford, CA: Stanford University Press, 2006), p. 235.

85. The "Annan Plan," so called because it was put forth by then UN Secretary-General Kofi Annan, was the result of a high-level consultation co-chaired by the UN secretary-general and the chairperson of the African Union Commission. It outlined a three-phased UN support to the African Union Mission in Sudan that comprised a UN Light Support Package, a UN Heavy Support Package, and a Hybrid Operation Force. See "High Level Consultation on the Situation in Darfur: Conclusions," United Nations, November 16, 2006. Available at http://www.un.org

86. "Diplomat Views China's Role on Darfur Issues, Stresses 'Even-Handedness.””

87. “China Says Ready to Work with West on Darfur,” Sudan Tribune, March 6, 2008.

88. Patrick Mutahi, “Africa Insight: Darfur- China’s Economic and Diplomacy Policy Pays Off,” All Africa, October 12, 2007.

89. See for instance, He Wenping, "China’s Unceasing Efforts to Resolve Darfur Issue,” China Daily, January 3, 2008.

90. “Interview with China's Special Envoy on China-Sudan Oil Cooperation,” People's Daily, March 17, 2008.

91. Li Anshan, "China and Africa: Policy and Challenges," China Security Vol. 3, No. 3 (Summer 2007), p. 77.

92. Jonathan Holslag, “China's Diplomatic Maneuvering on the Question of Darfur," Journal of Contemporary China Vol. 17, No. 54 (February 2008), p. 83.

93. Richard McGregor, "Chinese Diplomacy 'Hijacked' by Companies," Financial Times, March 17, 2008.

94. Holslag, "China’s Diplomatic Maneuvering on the Question of Darfur,” p. 83.

Beverley Loke is a $\mathrm{PhD}$ candidate in the Department of International Relations at the Australian National University (ANU), Canberra, Australia. 